\title{
GASTRO-ENTERITIS IN INFANCY
}

\section{AN ACCOUNT OF 286 CASES TREATED IN A GENERAL PAEDIATRIC HOSPITAL}

\author{
BY \\ N. M. MANN, SHEILA ROSS and W. H. PATTERSON \\ From Booth Hall Hospital, Manchester
}

(RECEIVED FOR PUBLICATION FEBRUARY 25, 1952)

Gastro-enteritis in infancy still remains one of the most challenging problems in paediatrics. In 1945 deaths from diarrhoea and enteritis accounted for $11 \%$ of the total infant mortality (Martin, 1949). The death rate has continued to fall, and in 1948 2,304 infants under 1 year of age, or $2 \cdot 88$ per 1,000 live births, died from the disease in England and Wales (Registrar-General, 1950). This has led Moncrieff (1950) to state:

'The preventive service has to a large extent won its fight against the scourge of infective diarrhoea as a national problem, although this is no excuse for allowing breast-feeding to decline still further or for slackening every effort to prevent outbreaks on a small scale in institutions. The new antibiotics and a better understanding of the clinical management of the infant with the "diarrhoea and vomiting" syndrome may lower the death rate even further.'

The object of this paper is to discuss the diagnosis and the management of the disease in a general paediatric hospital in Manchester, with a brief historical introduction to the problems of the past.

Gastro-enteritis in infancy is largely a social disease, and Cruickshank (1943) summed it up as an infection of artificially fed infants living in the bad and overcrowded housing of poor urban districts.

\section{Historical}

The incidence of diarrhoeal diseases in this highly industrial city has always been high. The mortality per 1,000 live births has usually exceeded that for England and Wales and at one period it was the highest in the land. Thus, in the Public Health Report for 1903 is the rueful comment, 'Manchester occupies the usual position relative to other towns'. At the turn of the century, the mean annual mortality rate for 10 years was $812(38 \cdot 31$ per 1,000 live births) compared with the total of 36,000 deaths (31 per 1,000 live births) for the country in 1898 (Hutchison, 1940).

There has been a steady decline since except for a flare-up of the disease in 1911 and another brief and small rise in 1947
In 1950,37 babies under 1 year of age $(2 \cdot 4$ per 1,000 live births) died from this disease in Manchester. The city's position relative to the country as a whole and to certain other areas is shown in the accompanying table (Brown, 1950).

\begin{tabular}{|c|c|}
\hline & $\begin{array}{l}\text { Death Rate from Diarrhoea and } \\
\text { Enteritis in Infants under } 2 \text { Years } \\
\text { per } 1,000 \text { Live Births }\end{array}$ \\
\hline England and Wales & 1.9 \\
\hline $\begin{array}{c}126 \text { county boroughs and great } \\
\text { towns, including London }\end{array}$ & $2 \cdot 2$ \\
\hline $\begin{array}{ccc}148 & \text { smaller towns, population } \\
25,000 & \text { to } 50,000 & .\end{array}$ & $1 \cdot 6$ \\
\hline London Administrative County ... & $1 \cdot 0$ \\
\hline Manchester & $3 \cdot 0$ \\
\hline
\end{tabular}

The struggle against the disease began in 1894 when Dr. James Niven became Medical Officer of Health. His predecessor, Mr. Leigh, had initiated the conversion of midden-privies and cesspools to the pail closet system. For a time the health of the population was much improved, but this policy had failed. The houses were frequently round courts entered by a ginnel and the smaller streets were often blocked at one end. The air was 'oppressive and malodorous'. Urine trickled out from the closet chambers, and foul liquid soaked into the soil from the defective drains. "The excreta were collected in midden privies in the courts at the ends outside the houses and in the narrow back passages. Often as many as six to eight houses were served by one privy.' The conditions must have been well nigh unendurable. In order to alleviate some of the evils the Council separated the dry from the wet materials and the urine was collected in cesspools. Mr. Leigh estimates that " had the contents of these cesspools been collected in one place, they would have formed a lake $5 \mathrm{ft}$. deep and 16 times the area of St. Ann's Square' (9 acres !). The subject was once more taken up and a movement was made towards the conversion of pails to water-closets, and 
the scheme was almost complete by 1914 . This change was probably the biggest single factor in reducing the mortality from summer diarrhoea (Walker, 1951).

An intensive investigation of the causation of summer diarrhoea was carried out from 1903 to 1906. The Health Report for 1904 records an investigation into the home conditions and infant feeding of 111 fatal cases. The case notes provide a fascinating insight into the appalling social conditions and the contemporary ignorance of domestic hygiene and infant management. 'It was noticed that, on the whole, the separation of districts according to diarrhoeal death-rates marks also a social separation and also a separation in regard to cleanliness.'

It was noted even then that breast-fed babies remained comparatively well and generally escaped diarrhoea all the year round.

The report provided clear evidence of the direct spread of infection in many cases. Much could also be ascribed to contaminated milk. It was still necessary to explain the autumnal rise when the greater part of the mortality occurred.

The relationship between the house fly and the autumnal epidemics of diarrhoea was proved by the setting of fly traps by reliable householders under the supervision of the Ladies' Public Health Society. The correspondence between the high fly counts and the high weekly mortality from diarrhoea was startling.

While admitting that within the term ' diarrhoea' more than one disease was included, Dr. Niven believed that summer diarrhoea was a specific disease caused by a specific organism. In 1906 he received a letter from Professor Delépine, of the Department of Bacteriology in the University of Manchester, suggesting that:

\begin{abstract}
'Although the bacteriology of epidemic diarrhoea is still in an unsettled state, there is a fair amount of evidence indicating that this type of diarrhoea is connected with the presence of bacteria of the bacillus coli group or of allied bacilli. In this preliminary investigation it appeared to me that our object should be chiefly to ascertain to what extent flies were capable of carrying these bacteria about.'
\end{abstract}

This opinion is of particular interest in view of the present work on the role of $E$. coli in relation to the disease.

The great outburst of 1911 showed that the abolition of pails and middens did not entirely eradicate the disease and other means of propagation had to be investigated. A study of the life-cycle of the fly in horse manure heaps was made (Hewitt, 1910). With difficulty bye-laws were subsequently amended so that horse manure had to be carted out of the city every seven days. Unhappily, there was one serious defect-the distance of removal was not specified. 'Manure might be removed to another depot a few yards off and a whole brood of flies might be generated under the bye-laws.'

When he retired in 1923 and wrote his History of Public Health Effort in Manchester Dr. Niven concluded that the improvement in the death rate from diarrhoea could be attributed to two causes. One was the gradual increase in health visiting staffs and the instructions given at welfare centres, and the other was the speedy removal of horse manure to the country. Despite this prolonged and tremendous effort, he regretted that his task was unfinished, and ' in no one thing do $I$ regret that more than in regard to summer diarrhoea'.

\section{Present Series}

The present series of 286 cases covers a period of two years, 1949 and 1950 . They are those remaining out of 427 cases after an exhaustive scrutiny of their records by two experienced observers, with recourse to an experienced paediatrician for adjudication in doubtful cases.

We have reason to believe that it is still too common elsewhere to use the term ' gastro-enteritis' loosely in cases of diarrhoea and vomiting, and far beyond that which we know to be the upper age limit.

Our cases do not include any of the specific gastro-intestinal infections, namely Salmonella or Shigella sonnei dysenteries. The role of $E$. coli in relation to the disease has not been investigated in this series. It was notable until recently that most papers dealing with gastro-enteritis in infancy gave considerable prominence to the part played by parenteral infection. We were never happy in ascribing so much importance to the significance of this factor (Patterson and Smith, 1944) and are interested to note the increasing emphasis on gastroenteritis as a disease sui generis. Clinically we feel we can recognize with a fair degree of certainty the primary case of gastro-enteritis.

\section{Social Conditions in 1950}

The names of the 103 patients with gastro-enteritis admitted from the city in 1949 were submitted to the Child Welfare Department. Then a questionnaire was planned and sent to the various welfare centres where the health visitors concerned wrote their comments. Thirty-four of the houses were noted as poor. Sixty of the mothers attended no welfare centre. Both cod liver oil and orange juice were given regularly to 32 babies, and 23 babies had both occasionally. Eighteen babies had one or the other; 18 babies were not given either. No 
comment was made on 13 papers. It was surprising to hear from all the health visitors that many mothers did not know how to give these vitamins correctly. To be of any value, instructions for this simple procedure must be detailed and precise.

General care of the home and child was noted to be poor in 25 of the cases. This compared with $19 \%$ of our gastro-enteritis cases over a five-year period who were noted to be ' dirty on admission'.

Through the courtesy of the Child Welfare Department we were able to accompany the health visitors to see a few of the worst houses in the bad areas. We included some of the homes where we knew cases of gastro-enteritis had occurred.

The overcrowding was often appalling and many mothers were enduring obvious emotional strain. To discover the squalor and low standards of general hygiene in these houses was a shock and an acutely depressing experience. However, it must be said at once that a frequent comment made by health visitors was that ' considering the conditions they live in, it is surprising there isn't more gastroenteritis than there is '. A few debilitated children were seen but the majority appeared robust and well fed. There was general agreement on the considerable improvement in baby health since 1939, which confirms our hospital experience.

We mapped our cases for the five years and found the concentration of cases in the overcrowded areas. Thus, in one of the worst municipal wards there were 61 persons per acre and 39 cases occurred over the five-year period. However, overcrowding is only one factor and this is shown by the incidence of 26 cases in the new housing estate where the population density is only eight persons per acre.

\section{Hospital Accommodation}

The domiciliary management of gastro-enteritis is fraught with danger. Although 121 cases in 1949 were admitted within two days of the onset, yet the rapidity of change and deterioration is still insufficiently appreciated. In the six-year period, 1945-1950, 30 babies were admitted moribund and died within 12 hours of admission. Several of these died within a few minutes of arrival. In 1950 two babies were brought in dead. There should be the same attitude of emergency towards this disease as there is to the ' acute abdomen' and to meningitis. It is scarcely possible for the busy general practitioner to provide the frequent observation these infants need. They are better in hospital, or at least under skilled out-patient and domiciliary observation.

A high percentage of patients have to be admitted to hospital because of social conditions. The type of hospital varies in different areas. In some districts the infectious diseases hospital is expected to admit infants with gastro-enteritis. In others the paediatric implications in the management of the disease are held to merit admission to a hospital where specialized care of infants is available.

The cases under review were nursed in a children's hospital with 400 beds where the affected infants are nursed in cubicles. These were not constructed specifically for the purpose and they are far from adequate by modern standards. The inadequacy has often been accentuated by the hospital having too few nurses and too low a proportion of senior and experienced staff. For an infant sick with gastroenteritis, night follows day without respite for those looking after him.

The ideal management of gastro-enteritis is most likely to be attained in a unit specially constructed and staffed. But, as Smellie (1939) has said, 'The nursing of gastro-enteritis is fraught with difficulty, with anxiety and frequently with disappointments.' To concentrate a large number of cases in a unit which is unsatisfactory structurally and understaffed is striking an initial blow at morale which will be reflected in the results.

With this in mind we spread our cases over three cubicle units in which the maximum number of babies acutely ill with gastro-enteritis at any one time must never be more than six.

The difference between a good paediatric nurse and all others is seen in the management of infants with gastro-enteritis. Here we should like to pay tribute to many of our nursing staff, whose skill and judgment have sustained not only the infant, but often the doctors as well.

\section{Seasonal Incidence}

The disease occurs throughout the year with peaks in incidence and mortality in January and December. Except in 1949 there was no obvious increase in secondary gastro-enteritis during these months to account for this peaking.

\section{Age}

It has always been taken as axiomatic in this hospital that gastro-enteritis does not often occur after 18 months of age. It was interesting to find that this age was not exceeded in 912 cases over the six-year period 1945 to 1950 . This fact is of administrative value, since children with diarrhoea and vomiting over this age are likely to have dysentery and may be diverted to a fever hospital.

From Tables 1 and 2 it will be seen that the highest 
TABLE 1

ANALYSIS OF CASES IN 1949

\begin{tabular}{|c|c|c|c|c|c|c|c|c|}
\hline $\begin{array}{c}\text { Age } \\
\text { (Months) }\end{array}$ & $\begin{array}{l}\text { No. of } \\
\text { Cases }\end{array}$ & $\begin{array}{c}\text { Dehydrated } \\
\text { on } \\
\text { Admission }\end{array}$ & $\begin{array}{c}\text { Dehydrated } \\
\text { after } \\
\text { Admission }\end{array}$ & $\begin{array}{c}\text { No. } \\
\text { Dehydrated }\end{array}$ & $\begin{array}{c}\text { Dehydrated } \\
(\%)\end{array}$ & $\begin{array}{l}\text { No. of } \\
\text { Deaths }\end{array}$ & $\begin{array}{l}\text { Fatality } \\
\text { Rate (\% } \\
\text { All Cases) }\end{array}$ & $\begin{array}{c}\text { Fatality } \\
\text { Rate (\% } \\
\text { Dehydrated) }\end{array}$ \\
\hline $0-2$ & 51 & 15 & 36 & 51 & $100 \cdot 0$ & 12 & $23 \cdot 5$ & $23 \cdot 5$ \\
\hline 3-5 & 63 & 24 & 22 & 46 & 73 & 12 & 19 & 26 \\
\hline $6-8$ & 38 & 18 & 13 & 31 & $81 \cdot 5$ & 4 & $10 \cdot 5$ & $12 \cdot 9$ \\
\hline $9-11$ & 18 & 7 & 5 & 12 & 75 & 0 & 0 & 0 \\
\hline Under 1 year & 170 & 64 & 76 & 140 & $82 \cdot 3$ & 28 & $16 \cdot 4$ & 20 \\
\hline $12-18$ & 16 & 7 & 4 & 11 & $68 \cdot 7$ & 1 & $6 \cdot 2$ & 9 \\
\hline Total & 186 & 71 & 80 & 151 & $81 \cdot 1$ & 29 & $15 \cdot 5$ & $19 \cdot 2$ \\
\hline
\end{tabular}

incidence of the disease and the greatest risk from dehydration and death occur in the first six months, with the emphasis on the first two months of life.

\section{Causation}

The infective nature of the disease has always been well known clinically, and this aspect has been stressed recently by certain workers in relation to $E$. coli (Giles and Sangster, 1948; Taylor, Powell and Wright, 1949; Kirby, Hall and Coackley, 1950).

In 1949 there were $141(75 \%)$ cases of primary gastro-enteritis. In this group parenteral infections after admission developed in $47(33 \%)$ cases with $12(25 \cdot 9 \%)$ deaths. Of the 94 primary cases which did not become secondarily infected, only nine $\operatorname{died}(9 \cdot 5 \%)$.

In 1950 there were 61 primary cases of the disease and four died $(5 \cdot 6 \%)$, and 39 cases of secondary gastro-enteritis with six deaths $(15 \cdot 3 \%)$.

A number of infants contracted gastro-enteritis in the hospital. In 1949 the population at risk under 18 months was 1,114 , and 26 of these infants developed the disease. During 1950, 948 babies were at risk and 11 of these contracted gastro-enteritis.
In addition, we had 28 cases over the two-year period from other hospitals, homes and nurseries. Thus, 65 infants became victims of cross infection for various reasons and of these 10 died $(15 \cdot 4 \%)$.

Considerable care is taken to accommodate ' feeding problems' and babies with pyloric stenosis away from the general infant population of the hospital. Such infants can be adequately nursed in a general medical or surgical ward containing patients over 18 months old. Thus, during the twoyear period 1949-1950, none of the 39 cases of pyloric stenosis contracted gastro-enteritis.

In the same way, by reorganization and careful planning one of the associated children's homes of 75 children, with an average occupancy of 50 under 18 months, has been quite free of the disease for the last two years, whereas in 1947-1948, 16 cases of gastro-enteritis with 10 deaths had occurred.

However, the only sure way of preventing cross infection is to keep the baby out of hospital. The improved paediatric training of students, full use of the consultant domiciliary service, better homes and the increased availability of antibiotics should minimize the need for admitting babies.

TABLE 2

ANALYSIS OF CASES IN 1950

\begin{tabular}{c|c|c|c|c|c|c|c|c}
\hline $\begin{array}{c}\text { Age } \\
\text { (Months) }\end{array}$ & $\begin{array}{c}\text { No. of } \\
\text { Cases }\end{array}$ & $\begin{array}{c}\text { Dehydrated } \\
\text { on } \\
\text { Admission }\end{array}$ & $\begin{array}{c}\text { Dehydrated } \\
\text { after } \\
\text { Admission }\end{array}$ & $\begin{array}{c}\text { No. } \\
\text { Dehydrated }\end{array}$ & $\begin{array}{c}\text { Dehydrated } \\
\%\end{array}$ & $\begin{array}{c}\text { No. of } \\
\text { Deaths }\end{array}$ & $\begin{array}{c}\text { Fatality } \\
\text { Rate (\% } \\
\text { All Cases) }\end{array}$ & $\begin{array}{c}\text { Fatality } \\
\text { (Rate \% } \\
\text { Dehydrated) }\end{array}$ \\
\hline $0-2$ & 34 & 15 & 11 & 26 & $76 \cdot 4$ & 8 & $30 \cdot 7$ \\
\hline $3-5$ & 37 & 20 & 12 & 32 & $86 \cdot 4$ & 0 & 0 \\
\hline $6-8$ & 19 & 7 & 7 & 14 & $73 \cdot 6$ & 2 & 0 \\
\hline $9-11$ & 8 & 4 & 1 & 5 & $62 \cdot 5$ & 0 & $10 \cdot 5$ \\
\hline Under 1 year & 98 & 46 & 31 & 77 & $78 \cdot 5$ & 10 & 0 \\
\hline $12-18$ & 2 & 1 & 0 & 1 & 50 & 0 & $10 \cdot 2$ \\
\hline Total & 100 & 47 & 31 & 78 & 78 & 10 & $12 \cdot 9$ \\
\hline
\end{tabular}


TABLE 3

Comparison of Parenteral Fluid Replacement Method in 1949 and 1950

\begin{tabular}{|c|c|c|c|c|c|c|c|c|c|}
\hline \multirow{3}{*}{ Year } & \multirow{3}{*}{$\begin{array}{c}\% \\
\text { of } \\
\text { Cases }\end{array}$} & \multicolumn{2}{|c|}{ Intravenous } & & & \multicolumn{3}{|c|}{ Subcutaneous } & \multirow{3}{*}{$\begin{array}{c}\text { Percentage } \\
\text { Morbidity } \\
\text { (All } \\
\text { Methods) }\end{array}$} \\
\hline & & \multicolumn{2}{|c|}{$\begin{array}{l}\text { Scalp Vein } \\
\text { Infusions }\end{array}$} & \multicolumn{2}{|c|}{ Cut-down } & $\begin{array}{c}\text { Plus } \\
\text { Intravenous }\end{array}$ & $\underset{\text { Only }}{\text { Subcutaneous }}$ & & \\
\hline & & $\begin{array}{l}\text { No. of } \\
\text { Cases }\end{array}$ & $\begin{array}{c}\text { Total } \\
\text { Given }\end{array}$ & $\begin{array}{l}\text { No. of } \\
\text { Cases }\end{array}$ & $\begin{array}{c}\text { Total } \\
\text { Given }\end{array}$ & $\begin{array}{l}\text { No. of } \\
\text { Cases }\end{array}$ & $\begin{array}{l}\text { No. of } \\
\text { Cases }\end{array}$ & $\begin{array}{c}\text { Total } \\
\text { Given }\end{array}$ & \\
\hline 1949 & $81 \cdot 6$ & 28 & 43 & 67 & 99 & 52 & 33 & 147 & $5 \cdot 8$ \\
\hline 1950 & $97 \cdot 7$ & 61 & 83 & 15 & 17 & 10 & 2 & 13 & $1 \cdot 1$ \\
\hline
\end{tabular}

Family History

In the type of gastro-enteritis with which we have been dealing we have never been able to get a history from the same house of an adult or older child with the disease, but we have had infants in the susceptible age-group living in the same apartment or house, not necessarily related, who have contracted gastro-enteritis.

\section{Breast Feeding}

All the patients admitted were artificially fed. Breast-feeding was attempted by $58 \%$ of the mothers of the 186 babies with gastro-enteritis in $1949 ; 46 \%$ had been breast-fed for a month or more, and mortality was $15 \%$. The mortality for babies who had never been breast-fed was $20.5 \%$, a much lower figure than usual (Smellie, 1939; Gairdner, 1945). However, these are selected cases and a more accurate picture of the relation of morbidity and breast-feeding is given by Naish (1949).

\section{Clinical Types of the Disease}

The four main types of the disease which we have encountered are as follows:

Mild. This type did not progress to dehydration, which was avoided by careful management of the feeds on diluted milk.

Severe and Toxic. This type needed one infusion only of intravenous plasma, followed by recovery without difficulty on graded feeds over varying periods of time.

Severe, Toxic and Relapsing. This type responded initially to intravenous plasma, but on diluted feeds relapsed into the previous state of dehydration, requiring a second and even a third and fourth infusion of intravenous plasma until the disease subsided. The relapses, although a well-known feature of the disease, may, in some of our cases, have been due to a too rapid stepping-up in the quantity and quality of oral feeds.

Fulminating. This type is rare and did not occur in this series. In it a baby has one or two loose stools with profound toxaemia, and death occurs within 12 hours.
During 1950, when our experience had matured and practice was more standardized, the proportion of these types, on a clinical assessment only, was as follows:

$\begin{array}{lllll}\text { Mild } & . . & . . & . & 26 \% \\ \text { Severe } & \ddot{2} & \because 4 & 44 \\ \text { Severe and relapsing } & . . & 30 \%\end{array}$

Of these $41 \%$ required intravenous infusion within 24 hours of admission.

\section{Clinical Features}

With the prevalence of salmonella dysentery, particularly the $S$. typhi-murium variety, in recent

TABLE 4

COMParison of Gastro-Enteritis With Salmonella Dysentery

\begin{tabular}{|c|c|c|}
\hline & Gastro-enteritis & $\begin{array}{l}\text { Salmonella } \\
\text { Dysentery }\end{array}$ \\
\hline$\overline{\text { Age }}$ & Up to 18 months & Any age \\
\hline Family history & $\begin{array}{l}\text { No child over } 18 \\
\text { months or adults }\end{array}$ & $\begin{array}{l}\text { Any member of the } \\
\text { family }\end{array}$ \\
\hline $\begin{array}{l}\text { Duration of symp- } \\
\text { toms before admis- } \\
\text { sion }\end{array}$ & 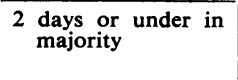 & Usually longer \\
\hline Pyrexia & $\begin{array}{l}\text { Rare, often sub- } \\
\text { normal tempera- } \\
\text { ture }\end{array}$ & $\begin{array}{l}\text { Always present with } \\
\text { first sign of infec- } \\
\text { tion }\end{array}$ \\
\hline Anorexia & Prominent symptom & Less often present \\
\hline Response to diet & $\begin{array}{l}\text { Diluted feeds only } \\
\text { tolerated }\end{array}$ & $\begin{array}{l}\text { Full feed often toler- } \\
\text { ated if vomiting not } \\
\text { a symptom }\end{array}$ \\
\hline Vomiting & Always present & Infrequent \\
\hline Diarrhoea & Watery stools & $\begin{array}{l}\text { More frequent in } \\
\text { number but small } \\
\text { and usually less } \\
\text { watery }\end{array}$ \\
\hline Blood & Exceptional & $\begin{array}{l}\text { Present, with much } \\
\text { mucus }\end{array}$ \\
\hline Organism & Nil specific & Salmonella \\
\hline Dehydration & $79 \%$ & $10 \%$ \\
\hline Relapses & $30 \%$ & $\begin{array}{cr}\text { Rarely, } \\
\begin{array}{c}\text { organism } \\
\text { excreted }\end{array} & \text { although } \\
\text { still }\end{array}$ \\
\hline $\begin{array}{c}\text { Duration of acute } \\
\text { phase }\end{array}$ & 12 days & 5 days \\
\hline Mortality & $12.7 \%$ & $2.5 \%$ \\
\hline $\begin{array}{l}\text { Infectivity for: } \\
\text { Nursing staff } \\
\text { Patients }\end{array}$ & $\begin{array}{l}\text { Never } \\
12 \% \text { under } 18 \text { months }\end{array}$ & $\begin{array}{l}\text { Often } \\
40 \% \text {-any age }\end{array}$ \\
\hline
\end{tabular}


years we have had the opportunity of comparing our type of gastro-enteritis cases with Salmonella dysentery (40 cases, one death). Many of the infants sent in as cases of gastro-enteritis were in fact cases of dysentery (Table 4).

\section{Clinical Examination and Assessment of Dehydration}

Although otitis media was found to occur infrequently, nevertheless a daily examination of the ears was encouraged. An initial specimen of urine was taken for microscopy and the examination repeated during any prolonged illness to ensure the absence of infection. The examination of three specimens of faeces was carried out as a routine. Daily palpation of the liver edge from the outset helps in detecting early enlargement should the disease be prolonged. Daily inspection of the mouth and oral hygiene are essential at all times, particularly during intravenous therapy. A refusal to feed should lead to inspection of the mouth before anorexia is considered to be the cause.

Assessment of shock and dehydration was made on clinical signs in all cases. A full examination was found to be necessary always, as dehydration may be more apparent in one part of the body than another.

Cyanosis and coldness of the peripheries, apathy, or anxiety with irritability and restlessness herald the danger of cerebral anoxia (Kerpel-Fronius, 1950). Cyanosis and hyperpnoea may be misinterpreted and attributed to an early pneumonia.

The daily weight, the charting of stools, vomits and frequency of urine are all helpful in the total assessment. The charted description of the stool is not always reliable. The very watery stool with a minimum of sediment is often wrongly interpreted as urine. The essential information is the size and the degree of wateriness of the stool. This is only obtained by frequent visits to the bedside. At this stage of the disease it is often possible to see a stool passed. There comes a time when one more stool or vomit will precipitate collapse. This should be anticipated and prevented.

The fat baby presents the most difficult problem in assessment. He looks far better than he really is, and his appearance combined with hesitancy over the technical difficulties, constitute a danger of delaying intravenous therapy too long.

The size of the fold of the abdominal skin that can be picked up (Alexander and Eiser, 1943), the falling weight, poor appetite, listlessness and apathy are signs that call for intravenous therapy.

\section{Biochemical Investigations}

A minimum of biochemical investigations was carried out. At first facilities were not easily available for micro-work. In the meantime, confidence from experience and reliance on clinical judgment had developed so that when the opportunities for full investigations became possible they were not fully used.

Most of our cases required a day's intravenous hydration only, and in these investigations were not necessary, as efficient treatment was possible without them. In other cases in which repeated intravenous therapy was needed, probably more investigations should have been made. Nonetheless, relying on the accumulated knowledge of the pioneer work on body chemistry, salt and water requirements, infantile kidney function, with intravenous therapy limited to one day, it was still possible to achieve safe and effective treatment without relying on biochemical findings (Kerpel-Fronius, 1949). However, we do show three deaths from intravenous therapy probably due to over-hydration, and not as far as we know to mistakes in the qualitative content of the fluid given. We found daily weighing one of the most useful guides to progress, and confirm Young's and McCance's (1943) statement that change in weight is a more sensitive index of water balance than serum chemistry.

\section{The Basis for Treatment}

Shock. Acute gastro-enteritis with dehydration is essentially a condition similar to shock. Marriott (1920) first claimed that the entire clinical picture of toxic, shocked infants following diarrhoea could be explained on the basis of water loss from the body, with slowing of the peripheral blood flow and a resulting anoxia of the stagnant type (Utheim, 1920).

Kerpel-Fronius (1948) re-emphasized the importance of this pioneer work and later verified the assumption that the blood supply to the brain is also diminished. A close correlation was found between the decrease of the oxygen saturation of the cerebral venous blood and anhydraemic shock. The cerebral symptoms of depression, of restlessness and of altered consciousness characteristic of a toxic condition in dehydration appeared when the oxygen saturation of the cerebral venous blood approached $25 \%$. When this decreased to $15 \%$ deep coma was observed (Kerpel-Fronius, 1950).

Starvation. Marriott (1920) found that if anhydraemic dogs were fed they developed diarrhoea and vomiting and died sooner than if they were completely starved. He concluded that anhydraemia produced a functional incapacity in the gastro-intestinal tract to tolerate foods. He regarded this as an adequate explanation of Finkelstein's observation that the giving of food to dehydrated infants aggravated the symptoms of toxicosis. Accordingly, if the infant is starved but 
the water intake is maintained, life can be prolonged. Nearly all paediatricians recommend this, since excessive water loss renders recovery impossible (Powers, 1926; Smellie, 1939; Field, MacCarthy and Wyllie, 1943).

Correction of Water and Salt Depletion. Freund (1904) first noticed the variation of the artificially fed infant's weight curve and explained it by the everchanging water-content of the body. Marriott $(1919,1920)$ observed that the weight-loss was proportional to water-loss. Clinical signs of dehydration in the adult are well established when $6 \%$ of the total body weight is lost (Coller and Maddock, 1935).

Arnott and Young (1942) found that in children degrees of dehydration ranging from mild to moderate and severe were relieved by volumes of fluid representing $3-6 \%$ of the body weight.

The danger of excessive salt administration has been stressed repeatedly (Aldridge, 1941; McCance and Young, 1941). It has been estimated that the approximate normal sodium chloride maintenance allowance a day for a resting infant is $1 \mathrm{~g}$. (Butler and Talbot, 1944).

According to the dehydration, Dodd and Rapoport (1946) gave their infants saline-containing fluid in amounts equal to $5-10 \%$ of the body weight plus the maintenance requirements in the first 24 hours. When diarrhoea continued, one and onehalf to two times the basal amount of electrolyte was supplied.

\section{Management}

The prolonged nature of the disease and the continuity of observation demanded of the nursing and medical staffs imposes a considerable strain on morale. With no specific therapeutic agent, treatment still remains a problem of management.

In considering therapy we must state that it is our firm conviction that castor oil has no place in the treatment of gastro-enteritis. Its use is irrational and harmful. Gastric and bowel 'washing-out' have little to commend them, and when unskilfully performed may precipitate shock or add the final embarrassment to a toxic infant.

The essential principles are (1) treatment of shock with intravenous plasma and warmth, combined with (2) the correction of dehydration by intravenous replacement of the salt and water lost, equivalent to $10 \%$ of the actual body weight on admission, and (3) alimentary rest with clear fluids by mouth and the regrading of feeds according to response.

Treatment of Shock. In this grave medical emergency intravenous plasma is life-saving and is the single, most effective agent available at present
(Bessau and Uhse, 1939; Kerpel-Fronius, 1949). No precise scheme of dosage has been followed. The 'half-bottles' $(200 \mathrm{ml}$.) of dried plasma are made up with $400 \mathrm{ml}$. of distilled water and the full amount given. In very small or marasmic infants it is safe to give about $10-20 \mathrm{ml}$. per $\mathrm{lb}$. body weight at first and then re-assess. Only the minimum quantity of fluid should be given to ensure hydration, and the infusion stopped.

Rates of Infusion. To overcome shock and to replace the $10 \%$ body weight lost (Dodd and Rapoport, 1946) the initial infusion is given quickly; $10 \mathrm{ml}$. per lb. body weight is run in rapidly and then the remainder at about $2 \mathrm{oz}$. per hour until dehydration is corrected. In marasmic infants a minimal quantity to overcome shock at about $1 \mathrm{oz}$. per hour is safest. In bigger babies, who are very shocked, this rate has been quickened to $3 \mathrm{oz}$. per hour until improvement has occurred.

Since some babies lose more than $10 \%$ of the body weight, frequent assessments are made so that the faster rate of flow may be prolonged till the baby is judged fully hydrated.

The usual maintenance requirements are calculated at $2-2 \frac{1}{2} \mathrm{oz}$. per pound daily and given at about $1 \mathrm{oz}$. hourly.

When the plasma has been run through and chlorides are present in the urine, the correction of dehydration is completed with $5 \%$ glucose alternating with $5 \%$ glucose and $\mathrm{N} / 5$ saline or $5 \%$ glucose and half-strength Hartmann's solution, given at the appropriate rate of flow.

We have adopted a conservative attitude about attempting to replace lost potassium intravenously. The rapid recovery from shock and dehydration in most of our patients allowed us to avoid the undoubted risk of giving potassium. In the relapsing case we were prepared to give potassium orally.

Although routine blood calcium levels were not estimated we were alert to the possibility of hypocalcaemia (Rapoport, Dodd, Clark and Syllm, 1947). Two babies had convulsions when in the stage of shock and dehydration. There were no associated hypocalcaemic signs and recovery took place following the infusion of plasma by vein. The convulsions were considered to be due to cerebral anoxia. It has been suggested that the occurrence of tetany in Rapoport's cases was probably due to over-treatment (Payne, 1950).

During the infusion on the first day no fluids by mouth are given to ensure complete alimentary rest. On the second day oral fluids are introduced as one-fifth normal saline, preferably on a 'pyloric schedule' of small hourly or two-hourly amounts, increasing in quantity at longer intervals. Ideally, this should start just before the intravenous infusion 
is discontinued. In bigger babies it is an advantage to sweeten the saline with saccharine and to flavour it with a little orange juice.

In the immediate post-infusion period, when shock has been overcome and the infant is restful and diarrhoea and vomiting have ceased, it does not matter if the full fluid requirements are not given. It is more important at this stage to allow the infant uninterrupted sleep through the night. Diluted milk mixtures are introduced at alternate feeds on the third day and the same mixture is given for all feeds on the fourth day. After this fairly standardized scheme no fixed plan is followed, and we feel our way, strengthening the milk feeds according to the infant's response in terms of stools, vomits and the daily weight.

Milk Feeds. For the smaller babies evaporated milks are nearly always used, beginning with a $1: 12$ dilution (protein $0.78 \%$, fat $0.82 \%$, carbohydrate $6.05 \%$ ) to a $1: 8$ (protein $1.17 \%$, fat $1.23 \%$, carbohydrate $6.58 \%$ ). When the infant is stabilized on a $1: 4$ dilution, $2-5 \%$ dextrimaltose is added and the effect on the stools observed. The next step is a gradual change of one feed a day to half cream dried milk with dextrimaltose.

For the bigger babies, varying dilutions of skimmed cow's milk are given and peptonized for 20 minutes if vomiting is a prominent feature. Evaporated milk may be taken better by some babies. When the baby is stabilized on a full skimmed milk and dextrimaltose a gradual change to a halfstrength whole milk is made, and this is stepped up quickly if necessary.

Before discharge all infants are having full feeds with sugar.

The approximate time taken in various cases in 1950 to resume original feeds was as follows:

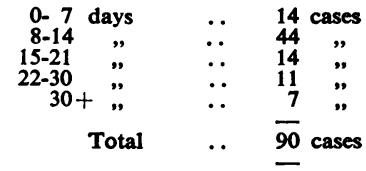

In $1949,25 \%$ of the babies took three weeks and over before they were taking their original feeds. In 1950 we had expected this percentage to fall, as particularly close observation was kept on the stools in the hope of strengthening feeds more quickly; however, the proportion remained about the same, $24 \cdot 4 \%$.

\section{Anorexia}

This was much less of a problem in 1950 than in 1949. We are convinced that this improvement has followed from earlier intravenous therapy.

The loss of appetite is intractable and this acutely difficult problem arises particularly in the baby of weaning age. Risks have to be taken with the diet and the ward sister is best left to stimulate the appetite in any way she can. Fat-free savoury and sweet foods should be tried (Abrahams and Widdowson, 1937). It is worth while questioning the mother about the baby's habits of feeding. He may have a preference for a cup, spoon or teat. If she is competent at feeding him, it may be of value to accommodate her and let her contribute to the struggle. However, in most cases plasma, reconstituted in $5 \%$ glucose, has to be given intravenously and can always be relied on to stimulate the appetite.

In some of our cases where, following initial improvement, the infant's condition entered a 'doldrum', a transfusion of fresh, whole blood seemed to give the necessary push towards recovery.

\section{Treatment of Complications}

Chemotherapy. Like all workers with this dangerous disease we are constantly on the look out for a specific therapeutic agent and we have tried sulphonamides, penicillin, streptomycin, chloromycetin, aureomycin and polymixin. Of these, polymixin held out most promise in our experience, but equivocal reports from other centres have led to its withdrawal (Parrish, 1950).

In the absence of a specific therapeutic agent the pushing of non-specific chemotherapeutic agents may be harmful in detracting attention from the allimportant, prompt relief of dehydration. However, their use in secondary infection arising during the course of the disease is rational and helpful.

Liver Failure. In 1949 the cause of death in two, and probably a third infant was considered to be liver failure. In 1950 this complication was not recognized in any case.

Jaundice or oedema was not present in any of the above three fatal cases. In one infant aged 13 months gross liver enlargement occurred but without haemorrhagic signs. No parenteral infection was found. The average daily calorie and protein intake was 9.8 and $0.28 \mathrm{~g}$. per pound respectively over a 17-day period before death. There was no necropsy. The second death was that of a fat, 7-month-old baby who was starved excessively and in whom intravenous therapy was delayed. Over a 19-day period before death the average daily calorie and protein intake was 5.4 and $0.5 \mathrm{~g}$. respectively. The liver had become enlarged and intravenous plasma and $2.5 \%$ casydrol was given without effect. The damage appeared to be irreversible. Haematemesis and melaena preceded convulsions and death. At necropsy there was widespread fatty infiltration of the liver but no necrosis was evident. 
The third fatality occurred in an infant of 3 months. His was a mild case and he relapsed at home after discharge from hospital. After readmission he had a calorie intake of 2.4 per pound, of which $0.16 \mathrm{~g}$. was protein. There was excessive starvation and inadequate parenteral fluid. He was unexpectedly found dead in his cot. Necropsy showed widespread fatty infiltration of the liver, but no necrosis. Schlesinger, Payne and Burnard (1949) in a study of liver damage in gastro-enteritis found two main pathological features, cell damage and necrosis or fatty infiltration. They concluded that further studies were needed to elucidate the exact nature and order of events in these liver damage cases.

In spite of the extensive use of plasma only one infant, as far as we are aware, developed homologous serum jaundice. This infant recovered from a severe relapsing type of gastro-enteritis requiring two intravenous plasma infusions. Seventy-two days after the first plasma infusion she suddenly became ill at home with jaundice and after two days' illness was readmitted moribund and died four hours later. The liver showed severe hepatitis.

\section{Techniques}

Morbidity. Our own experience and a study of the literature (Weihl, Rapoport and Dodd, 1947; Alexander, 1948; Todd, 1951) reveal that treatment itself has its hazards with its own morbidity and mortality rate. Efficient technique will reduce sepsis. Experienced judgment and careful fluid control for a minimum period will prevent overhydration. The life-saving value of plasma has to be balanced against the risk of homologous serum jaundice and death.

Of the various techniques attempted (Tables 3 and 4), scalp venepuncture proved to be the simplest and caused least infection. The particular method employed has been described before (Mann, 1951).

Mortality. In discussing this aspect of gastroenteritis, while not minimizing recent advances in therapy, we have, by experience, been impressed by the variability in the virulence of the disease from time to time, and indeed in various parts of the country at the same time. We would counsel a healthy scepticism about therapeutic claims and a continued alertness on the part of those called upon to deal with local epidemics occasionally.

Important factors in mortality are age, previous nutrition, degree of dehydration and additional infection.

The average death rate in the two-year series was $12.7 \%$. In the dehydrated babies under 1 year $16.45 \%$ died. The disease is most lethal for babies under 9 months old. The only death over 1 year occurred from liver failure. In 1950 the only two babies to die outside the 0-2 months age group were a mongol and the baby with homologous serum jaundice.

Infants who are $80 \%$ or under of their expected weight are said to be marasmic (Williams, Bishop and Young, 1949). On this basis $18(9.6 \%)$ babies were regarded as marasmic when they were admitted in 1949 and four of these died from gastro-enteritis. The relief of dehydration in the infant already marasmic presents special difficulties in giving safe quantities of intravenous fluid.

All babies who died were dehydrated, and the immediate treatment of shock and intravenous replacement of the salt and water lost is the prime factor in reducing the mortality rate.

As would be expected, the development of infection increases the mortality. In $1949,9 \%$ of cases with primary gastro-enteritis died. When infection developed, usually respiratory in origin, the mortality rose to $25.5 \%$. The mortality from secondary gastro-enteritis was $17 \cdot 7 \%$.

During $1950,15 \cdot 5 \%$ of the secondary gastroenteritis cases died compared with $5 \cdot 6 \%$ of the primary cases.

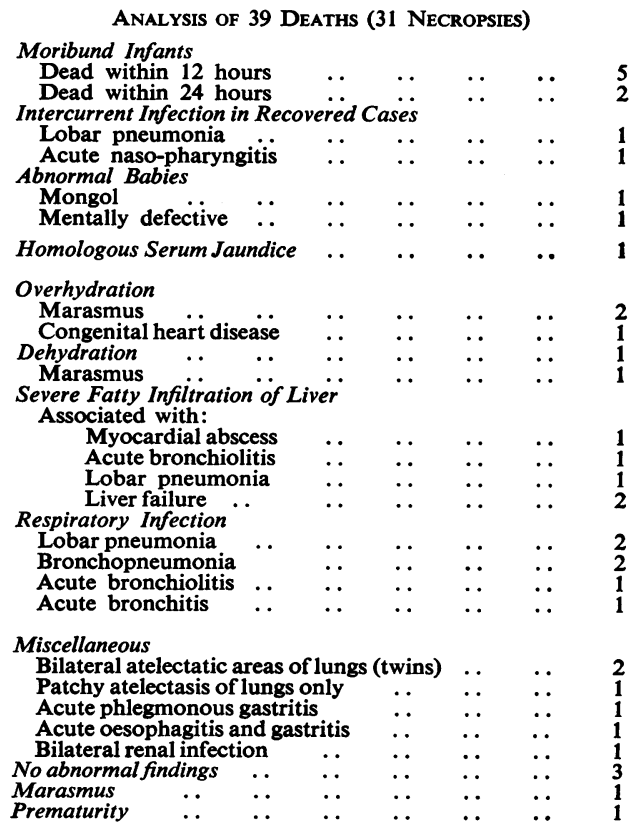

In the group with severe fatty infiltration of the liver one, and probably two, babies developed liver failure from excessive starvation. The only baby to have an intragastric drip was given an adequate protein and calorie intake. Nevertheless, gross enlargement of the liver developed and death 
probably occurred from liver failure. No postmortem examination was done in this case.

In 1950, apart from the severe hepatitis of the homologous serum jaundice case, only one liver of seven cases brought to necropsy showed a moderate degree of fatty change.

Over a 10-month period in 43 consecutive cases of gastro-enteritis with dehydration the only death was that of a moribund baby who died within one and three-quarter hours of admission, despite immediate intravenous plasma. Necropsy revealed that all the cerebral venous sinuses were thrombosed.

\section{Mortality of Other Surveys}

Since 1939, when Smellie reported a mortality of $48 \%$ in 500 cases, the death rate has steadily declined in Great Britain. Alexander (1948) reported a mortality of $8.6 \%$ in dehydrated babies under 1 year. In a series of 52 dehydrated cases Banks (1949) recorded a mortality of $17 \%$. KerpelFronius, Varga and Kun (1950) suggests that a mortality of 10 to $15 \%$ is attainable with modern therapy.

In America, Karelitz and Schick (1931), using continuous intravenous therapy, had an overall mortality of $23 \%$. Weihl et al. (1947) reviewed 221 cases of diarrhoea from all causes under 1 year and reported a fatality rate of $9 \cdot 1 \%$. Prince and Bruce (1948) surveyed four years of severe diarrhoea in infants. There were 62 deaths in $\mathbf{5 7 0}$ cases. The mortality of $10.92 \%$ could be corrected to $7.5 \%$. Mitchell, Donald and Birdsong (1949) reported a mortality of $5.3 \%$ in 396 cases of diarrhoea from all causes.

\section{Assessment of Results}

As early as 1894 Dr. Niven was agitating for the training of school girls in infant management and domestic hygiene. He realized that much of the high mortality from diarrhoea and vomiting could be attributed to the poor conditions of the infants when they were overwhelmed by the disease.

The difference in recent published mortality figures compared with those of 10 years ago in Great Britain is very striking. The incidence of the disease is less but it is still common. However, the babies are much fitter and better able to endure the rigours of the disease and its treatment.

The second contribution of major importance has been the early use of intravenous plasma. With it must be taken into account the third factor, the importance of medical and nursing experience.

As soon as gastro-enteritis units were set up the mortality dropped. In one unit the importance of continuity of experience has been recognized. Treatment has been supervised by a doctor of at least four years' experience. Off-duty and holiday relief is provided by resident medical officers familiar with the established routine. A further fall in the fatality rate from the disease appeared to be directly related to the training of the nursing staff (Alexander, 1948).

In our own hospital the results have improved year by year. Those obtained in 1950 were in the third year of experience of one of us as resident medical officer, who had access to all three units. The sisters of the baby wards remained continuously in charge, and for a year past their off-duty periods have been covered by a second, junior sister.

However, it should be noted that our series did not include any cases of epidemic neonatal diarrhoea, of which we have no experience. The average mortality from the disease in this age-group is $40 \%$ (Anderson and Nelson, 1944; Kirby et al., 1950).

\section{Discussion}

One of the earliest lessons learned in management is how rapidly these infants can deteriorate. Continuity of observation is a principle that has to be constantly practised. On off-duty days the briefing of a skilled deputy at the bedside to ensure this continuity is an important hospital ritual. The experience of the nurse-in-charge should also be known if the ward sister is off duty.

In the majority of cases needing intravenous therapy the emphasis is on the treatment of shock rather than on intravenous alimentation and this is completed in 24 hours. There must be few diseases so immediately rewarding and satisfying to treat. More often than not the moribund baby recovers when least expected.

However essential intravenous plasma may be, it is only one item in treatment and its value is wasted if careful regrading of feeds is not followed during the succeeding and equally critical stage.

When the disease is prolonged for two weeks or more it would be ideal to allow complete alimentary rest for long periods and feed the baby entirely by vein. However, efforts to achieve this are limited by the onset of phlebitis, usually within 48 to 72 hours, and if the vein has been cut and cannulated, it cannot be used again. Furthermore, there is always the risk of sepsis and septicaemia (Williams et al., 1949; Kirby et al., 1950). We have also lost a baby from this cause, which is more likely to occur with the cut-down method.

Some workers have suggested supplying the infant with arbitrary basal requirements of $1 \mathrm{~g}$. protein and 20-25 calories per pound body weight per day (Dodd et al., 1946; Williams et al., 1949) during parenteral therapy. In view of the technical complications of supplying theoretical requirements 
of protein by the intravenous route, we have aimed at ' keeping the baby going' until the disease subsides, tiding him over with intravenous plasma, $5 \%$ glucose and electrolyte solutions, and very occasionally $2 \cdot 5 \%$ casydrol for 24 -hour periods, as the occasion demands. This coincides with 24 hours of complete alimentary rest and renewed attempts to introduce graded milk feeds. The risk of liver failure is always our constant anxiety. It would be an advantage to know the minimum protein and calorie intake that would prevent it, although it must be remembered that toxaemia also contributes to this condition.

\section{Summary}

Two hundred and eighty-six infants with gastroenteritis were admitted to a general paediatric hospital of 400 beds in Manchester in the two years 1949 and 1950.

The disease has been a source of concern to public health authorities in such cities in the past. It is still a common malady, of variable severity, with an appreciable mortality, much of which is preventable. Both incidence and mortality have declined steadily.

Gastro-enteritis in the home is closely associated with social conditions and type of feeding, but the disease occurs in hospitals and institutions where young infants are congregated. In our hospital during 1949 a total of 1,114 infants were at risk and 26 of these contracted gastro-enteritis. In 1950, 11 infants developed the disease out of a total of 948. These figures include infants developing gastro-enteritis within 14 days of discharge.

Of 912 infants admitted to the hospital with acute gastro-enteritis, none was over the age of 18 months. It is suggested that in vomiting and diarrhoea occurring in children over this age, the term ' gastro-enteritis' should not be used.

The need for experienced medical care and skilled paediatric nursing is emphasized.

The mortality figures are analysed. In this particular series the overall death rate was $12 \cdot 7 \%$. In dehydrated babies under 1 year the mortality was $16.45 \%$. The figures did not include cases of epidemic neonatal diarrhoea and vomiting.

The variability in virulence of gastro-enteritis at different times is emphasized.

\section{APPENDIX}

All the non-protein solutions were prepared in the hospital pharmacy. The drip bottles were filled by a semi-automatic method (Norman, 1950). The finished products are examined visually against both a light and a dark background for the presence of foreign matter. It is found necessary to reject an average of only $1 \%$ of the bottles.
The needles were specially supplied by Messrs. Woolleys Ltd., Manchester.

Two charts were used. The nursing staff used the hourly fluid rate chart (Field et al., 1943). A modified weekly fluid balance, calorie, protein and electrolyte chart was used for prolonged cases (Field et al., 1943; Dodd and Rapoport, 1946).

An adherent paper scale, calibrated in ounces and cubic centimetres, was placed on each reservoir of fluid (Field et al., 1943).

An adequate acknowledgment to all those whose help was so generously given would outrun allotted space. It would include our colleagues on the staff-medical, nursing and secretarial ; the public health departments of Manchester and of Stretford; numerous paediatric units and infectious diseases hospitals whose hospitality and help were freely given to one or other of the writers.

\section{REFERENCES}

Abrahams, M. and Widdowson, E. M. (1937). Modern Dietary Treatment, 1st ed., pp. 225 and 240 . London.

Aldridge, A. G. V. (1941). Archives of Disease in Childhood, 16, 182. Alexander, M. B. (1948). Brit. med. J., 2, 973.

and Eiser, Y. (1943). Lancet, 2,810.

Anderson, N. A. and Nelson, W. E. (1944). J. Pediat., 25, 319.

Arnott, G. M. and Young, W. F. (1942). Lancet, 1, 523.

Banks, H. S. (1949). The Common Infectious Diseases. London.

Bessau, G. and Uhse, W. (1939). Dtsch. med. Wschr., 65, 1405.

Brown, C. M. (1950). Report of the Medical Officer of Health, Manchester.

Butler, A. M. and Talbot, N. B. (1944). New Engl. J. Med., 231, 585.

Cruickshank, R. (1943). Brit. med. J., 2, 159.

Coller, F. A. and Maddock, W. G. (1935). Ann. Surg., 102, 947.

Dodd, K. and Rapoport, S. (1946). J. Pediat., 29, 758.

Field, C. E., MacCarthy, D. and Wyllie, W.G.(1943). Brit. med. J., 1, 271.

Freund, $\dot{\mathbf{W}}$. (1904). Jb. Kinderheilk., 59, 421. Quoted by Utheim (1920).

Gairdner, P. (1945). Archives of Disease in Childhood, 20, 22.

Giles, C. and Sangster, G. (1948). J. Hyg., Camb., 46, 1.

Hewitt, C. G. (1910). The House Fly. Manchester.

Hutchison, R. (1940). Lancet, 2, 799.

Karelitz, S. and Schick, B. (1931). Amer. J. Dis. Child., 42, 781.

Kerpel-Fronius, E. (1948), Acta paediat., Uppsala, 36, 611.

- (1949). Personal communication.

- (1950). Personal communication. Archives of Disease in Childhood, 25, 156.

Kirby, A. C., Hall, E. G., and Coackley, W. (1950). Lancet, 2, 201.

Mann, N. M. (1951). Ibid., 1, 1230.

Marriott, W. McK. (1919). J. Amer. med. Ass., 73, 1173.

(1920). Amer. J. Dis. Child., 20, 461.

Martin, W. J. (1949). Brit. med. J., 1, 438.

Mitchell, J. E., Donald, W. D. and Birdsong, M. (1949). J. Pediat.,

35, 529.
Moncrieff, A. (1950). Brit. med. J., 2, 795.

McCance, R. A. and Young, W. F. (1941). J. Physiol., Lond., 99, 265.

Naish, F. C. (1949). Lancet, 1, 146.

Norman, R. (1950). Pharm. J., 165, 381

Parrish, J. H. (1950). Personal communication.

Patterson, W. H. and Smith, G. S. (1944). Brit. med. J., 2, 659.

Payne, W. W. (1950). Proc. roy. Soc. Med., 43, 616.

Powers, G. F. (1926). Amer. J. Dis. Child., 32, 232.

Prince, G. E. and Bruce J. W. (1948). J. Pediat., 33, 342.

Rapoport, S., Dodd, K., Clark, M. and Syllm, I. (1947). Amer. J. Dis. Child., 73, 391.

Registrar General (1950). Statistical Review of England and Wales for 1948, Part I, Medical. H.M.S.O. London.

Schlesinger, B., Payne, W. W. and Burnard, E. D. (1949). Archives of Disease in Childhood, 24, 15.

Smellie, J. M. (1939). Lancet, 1, 1026. (1949) Brit. med J 2,117.

Todd, M.'(1951). Lancet, 1, 982.

Utheim, K. (1920). Amer. J. Dis. Child., 20, 366.

Utheim, K. (1920), Amer. J. Dis. Child., 20, 366.

Walker, E. H. (1951). Personal communication.

Williams, Y. J., Bishop E. A. and Young, W. F. (1949). Archives of Disease in Childhood, 24, 159. Young, W. F. and McCance, R. A. (1943). Proc. roy. Soc. Med., 36,
219 . 